\title{
A COMPARATIVE STUDY IN THE CHANGES OF LIPID PROFILE BETWEEN OOPHORECTOMIZED AND NON-OOPHORECTOMIZED WOMEN UNDERGOING HYSTERECTOMY
}

\author{
Sukumar Mitra1, Seema Das²
}

${ }^{1}$ Associate Professor, Department of Obstetrics and Gynaecology, Medical College, Kolkata, West Bengal, India.

${ }^{2}$ Resident, Department of Obstetrics and Gynaecology, Medical College, Kolkata, West Bengal, India.

ABSTRACT

\section{BACKGROUND}

We wanted to determine the association, if any, between types of hysterectomy w.r.t. preservation of ovaries and tubes and lipid profile. Women without tubes and ovaries are more susceptible to acute changes in lipid profile. Lipid profile is also significantly affected by bilateral salpingectomy in spite of preservation of ovaries. What is known already is that, risk of CVD increases after natural menopause but association with surgical premature menopause is still to be validated.

\section{METHODS}

A comparative study was undertaken to analyse the changes in lipid profile between oophorectomized and non-oophorectomized women undergoing hysterectomy. 45 participants enrolled in three different categories of total abdominal hysterectomy namelycontrol group-10, bilateral salpingectomy + TAH (16) and BSO+TAH (19) done for benign conditions. Preoperative and consecutive postoperative lipid profiles were obtained.

\section{RESULTS}

Total cholesterol changes are incremental in both TAH + BLS and TAH + BSO group. This may be also an acute response to surgery but requires a long-term follow up. Over three months postoperative-triglycerides, -LDL, -Total Cholesterol increased in TAH group by $12.2 \%, 6.15 \%, 3.16 \%$ to $35.44 \%, 41.53 \%, 17.26 \%$ respectively. HDL decreased from $16.7 \%$ three months postoperatively to $11.2 \%$ after six months of surgery. In TAH + BLS, total triglyceride, LDL, Total Cholesterol increased from 7.3\%, 14.0\%, 7.8\% after three months postoperative to $27.9 \%, 24.03 \%, 11.4 \%$ following six months respectively. HDL decreased to $16.5 \%$ from the preoperative level after 3 months and $10.8 \%$ after six months. Among the TAH + BSO group, total triglyceride, LDL, total cholesterol raised to $14.9 \%, 22.5 \%, 14.0 \%$ from the baseline after three months respectively and further increased to $22 \%$, $32.3 \%, 21.9 \%$ after six months of surgery. HDL values showed a steady decline from $17.1 \%$ to $20.1 \%$ after three months and six months of surgery respectively.

\section{CONCLUSIONS}

Women with lower ovarian reserve might be susceptible to development of cardiovascular risk factors, particularly dyslipidaemia even during the reproductive life span. A long-term follow up should be done for women who have undergone surgical menopause with sacrifice of both tubes and ovaries.

\section{KEY WORDS}

Surgical Menopause, Lipid Profile, Cardiovascular Risk Factors

HOW TO CITE THIS ARTICLE: Mitra S, Das S. A comparative study in the changes of lipid profile between oophorectomized and non-oophorectomized women undergoing hysterectomy. J. Evolution Med. Dent. Sci. 2019;8(29):2362-2366, DOI: $10.14260 /$ jemds/2019/517

\section{BACKGROUND}

In view of lipid metabolism, adipose tissue and liver are the most important tissues for 17 beta estradiol, the main oestrogen source in a women's body. Lack of oestrogens in women after menopause may cause coronary heart disease. ${ }^{1}$ It is considered that $25 \%-50 \%$ of positive effect of oestrogens which are given to postmenopausal is connected with their action on lipid metabolism. ${ }^{1}$ In adipocytes, 17 beta estradiol can be stored as its esters with long chain fatty acids. ${ }^{1}$

'Financial or Other Competing Interest': None.

Submission 21-05-2019, Peer Review 04-07-2019,

Acceptance 10-07-2019, Published 22-07-2019.

Corresponding Author:

Dr. Seema Das,

Type 3/TS/212-M,

Near Welfare Hospital,

P.O. Kirandul, Dist.,

Dantewada-494556,

Chhattisgarh, India.

E-mail: cmadas0@gmail.com

DOI: $10.14260 /$ jemds $/ 2019 / 517$
It was proved that oestrogen receptors are present in adipocytes and hepatocytes, but their density is much lower than in gonads.

On the cellular level oestrogens regulate mRNA production for particular for particular proteins among which are proteins involved in lipid metabolism. ${ }^{1}$ In adipose tissue 17 beta estradiol has a direct effect on lipoprotein lipase (LPL) and hormone sensitive lipase. Indirect action of oestrogens on adipose tissue is connected with the stimulation of the releasing of other hormones which increase hormone sensitive lipase activity. To this group of hormones there belong catecholamines, growth hormone and glucagon.

In liver 17- beta estradiol regulates the rate of synthesis of structural apolipoproteins for VLDL \& HDL. In conclusion, 17- estradiol by regulating lipid metabolism in adipocytes and hepatocytes modulates the concentration of lipid substances in plasma ${ }^{1}$. The lack of 17-beta estradiol leads likely to various lipid metabolism disorders in women after menopause. 
Premature menopause and bilateral oophorectomy in young women are associated with increased incidence of cardiovascular disease, myocardial infarction \& overall mortality. Observational studies suggest an interval of 5$10 \mathrm{yrs}$ between loss of ovarian function \& increased risk of cardiovascular disease. Compared with men, women generally have a lower potential for suffering cardiovascular events, but the risk of such morbidities increases after menopause. The Framingham cohort showed that the gender difference in risk of cardiovascular diseases (CVD) diminishes with each 10-year progression of age and that the age at menopause is inversely correlated with CVD risk.

In this study we have followed up with the lipid profile of three groups of hysterectomy patient including total abdominal hysterectomy (TAH), TAH+bilateral salpingectomy, TAH+bilateral salpingo-oophorectomy. There have been studies in the literature regarding the effect of bilateral salpingo-oophorectomy on lipid profile and consecutive associated cardiovascular risks, but to the best of our knowledge there has not been a study on the effect of bilateral salpingectomy on lipid profile.

\section{Total Abdominal Hysterectomy and Bilateral} Salpingectomy v/s Bilateral Salpingo-Oophorectomy

Among women of reproductive age, hysterectomy is (in developed countries) the second most frequently performed surgical intervention, superseded only by Caesarean section. Women with only removal of uterus had 3 times greater risk of CVD, but if ovaries are also removed the risk rises 7 times. $^{2}$

In India, the incidence of hysterectomy is about $4-6 \%$ of adult Indian women out of which $90 \%$ are performed for benign indications. ${ }^{3}$ Another study from Gujarat pointed out that $7-8 \%$ of rural women and $5 \%$ of urban women had already undergone hysterectomy at an average age of 37 year. 4

Risk-reducing and elective salpingo-oophorectomies are the removal of the ovaries for the potential benefit of preventing long-term morbidity and mortality. The term riskreducing salpingo-oophorectomy implies that the ovaries are normal at the time of removal. Removal of the ovaries during hysterectomy is, indeed, a matter of debate. ${ }^{5}$ According to large case-control studies, oophorectomy and the resulting surgical menopause increase the long-term risk for cardiovascular, psychosexual and cognitive dysfunctions. ${ }^{6}$ Moreover, a prospective study showed that oophorectomy along with hysterectomy lowers the risk for ovarian cancer, whereas the incidence of fatal and non-fatal coronary heart diseases increased. As only one in 1500 women aged 50 years and one in 400-600 women aged 60-70 years develop ovarian cancer in the course of one year(National Cancer Institute, 2004), ${ }^{7}$ ovarian cancer remains a relatively rare disease, responsible for 16000 fatalities per year in the USA. Heart disease, in contrast, is a major killer causing 490000 deaths among American women annually. ${ }^{8}$ Thus, an overall significant negative association of the effect of oophorectomy with mortality (All causes) was found. Moreover, none of the groups (Or age groups) displayed a positive correlation between oophorectomy and increased survival. ${ }^{9}$ In contrast, a recent study failed to detect a significant increase in cardiovascular events after bilateral oophorectomy performed at the time of hysterectomy. ${ }^{10}$
However, while both the studies investigated large sample sizes, follow-up times were considerably different, i.e. patients in the National Health Service study in the UK were followed for 24 years, ${ }^{9}$ whereas data from the Women's Health Initiative study were evaluated for just 8 years after oophorectomy-which obviously limits the information content regarding the long-term effects on women's health. ${ }^{10}$ Accordingly, a prophylactic bilateral oophorectomy may do more harm than good. The removal of the ovaries at the time of hysterectomy should thus be approached with great caution, especially in premenopausal women. This is reflected by a guideline from the American College of Obstetricians and Gynaecologists (ACOG), which recommends conservation of the ovaries, at least for premenopausal women with no known genetic risk for ovarian cancer (ACOG, Practice bulletin No. 89; 2008).

After hysterectomy, the Fallopian tubes can no longer fulfil their previous physiological function. The blind-ended remnants of the Fallopian tubes may instead give rise to multiple complications, the most frequent $(35.5 \%)$ being hydrosalpinx (Morse, 2002,11 Repasy et al., 2009,12) which requires revision surgery in $7.8 \%$ of patients (Morse et al., 2006). ${ }^{13}$ Further possible problems originating from retained Fallopian tube remnants are summarized in Fig. 1( Basu and Ward, 2007;Singla, 2007; Ghezzi et al., 2009; Timor-Tritsch et al,14 Rezvaniand Shaaban, ${ }^{15}$ 2011).

Thus, bilateral salpingectomy concomitant with hysterectomy is widely recommended to avoid subsequent tubal pathology. 12

\section{METHODS}

This study has been conducted at Medical College Hospital Kolkata over a period of 6 months. Inclusion Criteria: Patients of reproductive age group attending gynaecology OPD for benign causes with cervical and endometrial biopsy report to rule out malignancy and previous no history of chemotherapy were included.

\section{Study Design}

Comparative study.

\section{Sample Size}

$10,16,19$ each in TAH, TAH+ BLS, TAH+ BSO respectively.

\section{Inclusion Criteria}

Age less than 45 yrs. selected for conservation of ovaries (Out of which 10 patients randomly selected for only hysterectomy and 16 patients selected for salpingectomy in addition to hysterectomy.

\section{Exclusion Criteria}

Patients with adnexal masses, proven gynaecological malignancies, deranged lipid profile preoperatively, previously known heart disease.

\section{Sampling Technique}

Random.

\section{IEC Clearance}

Approved and informed consent received. 


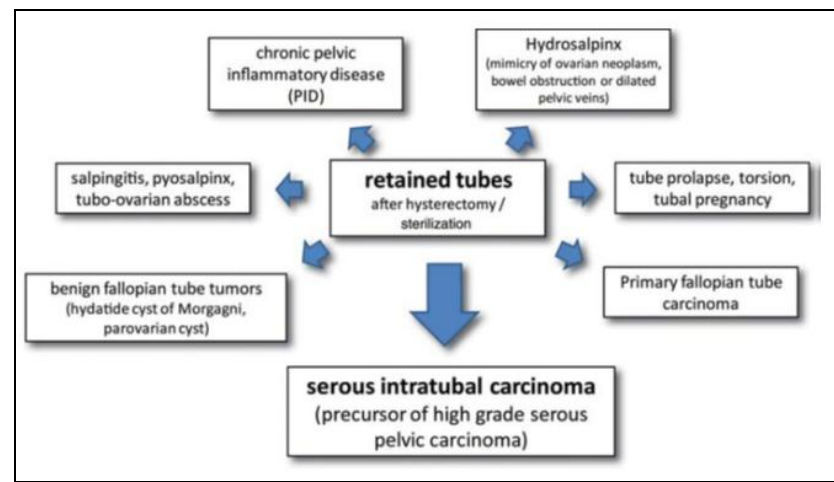

Figure 1. Human Reproduction, Vol. 26, No. 11 pp. 2918-2924, $2011^{12}$

\section{RESULTS}

\begin{tabular}{|c|c|c|c|c|c|c|c|c|}
\hline & & No. & Mean & SD & Mini. & Maxi. & Median & p-Value \\
\hline \multirow{3}{*}{ Age } & TAH & 10 & 42.7000 & .9487 & 40.0000 & 43.0000 & 43.0000 & \\
\cline { 2 - 7 } & TAH BLS & 16 & 42.5625 & 2.9205 & 35.0000 & 46.0000 & 43.0000 & $<0.0001$ \\
\cline { 2 - 6 } & TAH BSO & 19 & 47.4211 & 3.6563 & 42.0000 & 54.0000 & 48.0000 & \\
\hline \multicolumn{8}{|c|}{ Table 1. Distribution of Mean Age in Groups } \\
\hline
\end{tabular}

\begin{tabular}{|c|c|c|c|c|c|c|c|c|c|c|c|c|}
\hline \multicolumn{6}{|c|}{$\begin{array}{c}\text { Pre- Operative } \\
\text { (mg/dl) }\end{array}$} & \multicolumn{3}{|c|}{$\begin{array}{c}\text { Post-0p } \\
3 \mathrm{~m} \mathrm{(mg/dl)}\end{array}$} & \multicolumn{4}{|c|}{$\begin{array}{c}\text { Post-0p } \\
6 \mathrm{~m} \mathrm{(mg/dl)}\end{array}$} \\
\hline & TG & HDL & LDL & TC & TG & HDL & LDL & TC & TG & HDL & LDL & TC \\
\hline TAH & $\begin{array}{l}101.40 \\
\pm 21.49\end{array}$ & \begin{tabular}{|l|}
53.10 \\
\pm 8.13 \\
\end{tabular} & $\begin{array}{l}78.00 \pm \\
26.73\end{array}$ & $=\begin{array}{c}145.40 \\
\pm 20.4\end{array}$ & $\begin{array}{l}113.80 \\
\pm 17.05\end{array}$ & $\mid \begin{array}{c}44.20 \\
\pm \\
11.01\end{array}$ & \begin{tabular}{|c|c|} 
& $82.80 \pm$ \\
26.41 & \pm \\
\end{tabular} & $\begin{array}{l}150.00 \\
\pm 19.89\end{array}$ & $\begin{array}{l}137.37 \\
\pm 14.21\end{array}$ & $\begin{array}{c}47.10 \\
\pm \\
14.25\end{array}$ & $\begin{array}{l}110.40 \\
\pm 12.39\end{array}$ & \begin{tabular}{l|l}
40 & 170.5 \\
12.2
\end{tabular} \\
\hline $\begin{array}{l}\text { TAH } \\
+ \text { BLS }\end{array}$ & $\begin{array}{l}119.13 \\
\pm 25.18\end{array}$ & $\begin{array}{l}46.31 \\
\pm 6.12 \\
\end{array}$ & $\begin{array}{l}93.88 \pm \\
18.02\end{array}$ & $=\begin{array}{l}160.31 \\
\pm 16.94\end{array}$ & $\begin{array}{l}127.98 \\
\pm 25.02\end{array}$ & \begin{tabular}{|l|l}
41.31 \\
\pm 6.26
\end{tabular} & \begin{tabular}{l|l|}
1 & 107.00 \\
6 & \pm 20.27
\end{tabular} & $\begin{array}{l}171.63 \\
\pm 19.16\end{array}$ & $\begin{array}{l}152.31 \\
\pm 27.63\end{array}$ & $\begin{array}{l}38.63 \\
\pm 6.26\end{array}$ & $\begin{array}{l}116.4 \\
\pm 21.25\end{array}$ & $\begin{array}{ll}44 & 178.5 \\
25 & \pm 19.6\end{array}$ \\
\hline \begin{tabular}{|c|}
$\mathrm{TAH}$ \\
+ \\
$\mathrm{BSO}$
\end{tabular} & $\begin{array}{c}165.74 \\
\pm \\
12.74\end{array}$ & $\begin{array}{l}41.84 \\
\pm 6.12 \\
\end{array}$ & $\begin{array}{l}121.58 \\
\pm 23.06\end{array}$ & $\begin{array}{l}190.42 \\
\pm 25.14 \\
\end{array}$ & $\begin{array}{l}190.47 \\
\pm 25.14\end{array}$ & $\begin{array}{c}34.68 \\
\pm \\
25.00\end{array}$ & \begin{tabular}{l|l|} 
& 148.89 \\
\pm 22.55 & $=$
\end{tabular} & \begin{tabular}{l|l|}
9 & 217.05 \\
5 & \pm 22.72 \\
\end{tabular} & & \begin{tabular}{|l|l}
33.42 \\
\pm 8.21 \\
\end{tabular} & $\begin{array}{l}160.95 \\
\pm 22.23\end{array}$ & \begin{tabular}{l|l}
75 & 232.2 \\
23 & \pm 21.1
\end{tabular} \\
\hline \multicolumn{13}{|c|}{ Table 2. Summary of Changes in Lipid Profile Over 6 Months } \\
\hline \multirow{4}{*}{\begin{tabular}{|c|} 
\\
Pre - \\
Op Tg
\end{tabular}} & & & No. & Mean & \multicolumn{2}{|c|}{ SD } & Mini. & \multicolumn{2}{|c|}{ Maxi. } & \multicolumn{2}{|c|}{ Median } & $\begin{array}{l}\text { p- } \\
\text { alue }\end{array}$ \\
\hline & \multicolumn{2}{|c|}{ TAH } & 10 & 101 & \multirow{2}{*}{\multicolumn{2}{|c|}{\begin{tabular}{|l|l|}
0 & 21.4900 \\
0 & 25.1843 \\
\end{tabular}}} & \multirow{2}{*}{$\begin{array}{l}89.0000 \\
89.0000\end{array}$} & \multicolumn{2}{|c|}{152.0000} & \multicolumn{2}{|c|}{91.0000} & \multirow{3}{*}{$<0.0001$} \\
\hline & \multirow{2}{*}{\multicolumn{2}{|c|}{ TAH BLS }} & 16 & 119. & & & & \multirow{2}{*}{\multicolumn{2}{|c|}{\begin{tabular}{l|l} 
& 172.0000 \\
0 & 182.0000
\end{tabular}}} & \multirow{2}{*}{\multicolumn{2}{|c|}{\begin{tabular}{|l|}
114.0000 \\
165.0000 \\
\end{tabular}}} & \\
\hline & $\sqrt[1 g]{\mathrm{TAF}}$ & & \begin{tabular}{l|l}
19 & 1 \\
\end{tabular} & 165.736 & \multicolumn{2}{|c|}{\begin{tabular}{|l|l|}
0 & 25.1843 \\
8 & 12.7360
\end{tabular}} & 141.0000 & & & & & \\
\hline
\end{tabular}

\begin{tabular}{|c|c|c|c|c|c|c|c|c|}
\hline & & No. & Mean & SD & Mini. & Maxi. & Median & $\begin{array}{c}\text { p- } \\
\text { Value }\end{array}$ \\
\hline \multirow{3}{*}{$\begin{array}{c}\text { Total Tg } \\
3 \mathrm{~m}\end{array}$} & TAH & 10 & 113.8000 & 17.0542 & 95.0000 & 134.0000 & 118.0000 & \\
\hline & TAH BLS & 16 & 127.8750 & 25.0197 & 96.0000 & 179.0000 & 124.0000 & $<0.000$ \\
\hline & TAH BSO & 19 & 190.4737 & 15.2584 & 156.0000 & 226.0000 & 186.0000 & \\
\hline
\end{tabular}

\begin{tabular}{|c|c|c|c|c|c|c|c|c|}
\hline & & No. & Mean & SD & Mini. & Maxi. & Median & $\begin{array}{c}\text { p- } \\
\text { Value }\end{array}$ \\
\hline \multirow{2}{*}{$\begin{array}{l}\text { TG } 6 \\
\text { Mon. }\end{array}$} & TAH & 10 & 137.3750 & 14.2120 & 121.0000 & 158.0000 & 135.5000 & \\
\cline { 2 - 8 } & TAH BLS & 16 & 152.3125 & 27.6350 & 104.0000 & 210.0000 & 155.0000 & $<0.0001$ \\
\cline { 2 - 6 } & TAH BS & 19 & 202.1579 & 13.4340 & 184.0000 & 238.0000 & 198.0000 & \\
\hline \multicolumn{6}{|c|}{ Table 5. Distribution of Mean TG 6 Mon. in Groups } \\
\hline
\end{tabular}

\begin{tabular}{|c|c|c|c|c|c|c|c|c|}
\hline & & No. & Mean & SD & Mini. & Maxi. & Median & $\begin{array}{c}\text { p- } \\
\text { Value }\end{array}$ \\
\hline \multirow{2}{*}{$\begin{array}{c}\text { HDL } \\
\text { Pre-Op }\end{array}$} & TAH & 10 & 53.1000 & 8.1302 & 34.0000 & 64.0000 & 55.0000 & \\
\cline { 2 - 8 } & TAH BLS & 16 & 46.3125 & 6.1179 & 38.0000 & 59.0000 & 46.0000 & 0.0011 \\
\hline \multicolumn{8}{|c|}{ Table 6. Distribution of Mean HDL Pre-Op in Groups } \\
\hline
\end{tabular}

\begin{tabular}{|c|c|c|c|c|c|c|c|c|}
\hline & & No. & Mean & SD & Mini. & Maxi. & Median & $\begin{array}{c}\text { p- } \\
\text { Value }\end{array}$ \\
\hline \multirow{2}{*}{$\begin{array}{c}\text { HDL } \\
\mathbf{3} \mathbf{~ m}\end{array}$} & TAH & 10 & 44.2000 & 11.0131 & 34.0000 & 56.0000 & 41.0000 & \\
\cline { 2 - 8 } & TAH BLS & 16 & 41.3125 & 6.2580 & 30.0000 & 55.0000 & 41.5000 & 0.0067 \\
\cline { 2 - 6 } & TAH BSO & 19 & 34.6842 & 7.2958 & 25.0000 & 46.0000 & 35.0000 & \\
\hline \multicolumn{8}{|c|}{ Table 7. Distribution of Mean HDL 3 m in Groups } \\
\hline
\end{tabular}

\begin{tabular}{|c|c|c|c|c|c|c|c|c|}
\hline & & No. & Mean & SD & Mini. & Maxi. & Median & $\begin{array}{c}\text { p- } \\
\text { Value }\end{array}$ \\
\hline \multirow{2}{*}{$\begin{array}{c}\text { HDL } \\
6\end{array}$} & TAH & 10 & 47.1000 & 14.2552 & 30.0000 & 62.0000 & 49.5000 & \\
\cline { 2 - 8 } & TAH BLS & 16 & 38.6250 & 6.2597 & 28.0000 & 50.0000 & 39.0000 & 0.0022 \\
\cline { 2 - 5 } TAH BSO & 19 & 33.4211 & 8.2146 & 24.0000 & 48.0000 & 30.0000 & \\
\hline \multicolumn{8}{|c|}{ Table 8. Distribution of Mean HDL 6 Mon. in Groups } \\
\hline
\end{tabular}

\begin{tabular}{|c|c|c|c|c|c|c|c|c|}
\hline & & No. & Mean & SD & Mini. & Maxi. & Median & $\begin{array}{c}\text { p- } \\
\text { Value }\end{array}$ \\
\hline \multirow{3}{*}{$\begin{array}{c}\text { Pre-0p } \\
\text { LDL }\end{array}$} & TAH & 10 & 78.0000 & 26.7291 & 50.0000 & 103.0000 & 84.0000 & \multirow{3}{*}{$<0.0001$} \\
\hline & $\begin{array}{l}\text { TAH } \\
\text { BLS } \\
\end{array}$ & 16 & 93.8750 & 18.0217 & 62.0000 & 126.0000 & 97.5000 & \\
\hline & $\begin{array}{l}\text { TAH } \\
\text { BSO }\end{array}$ & 19 & 121.5789 & 23.0562 & 79.0000 & 172.0000 & 115.0000 & \\
\hline \multicolumn{9}{|c|}{ Table 9. Distribution of Mean Pre-Op LDL in Groups } \\
\hline & & No. & Mean & SD & Mini. & Maxi. & Median & \begin{tabular}{|c|} 
p- \\
Value
\end{tabular} \\
\hline \multirow{3}{*}{$\begin{array}{l}\text { LDL } \\
3 \mathrm{~m}\end{array}$} & TAH & 10 & 82.8000 & 26.4146 & 54.0000 & 107.0000 & 92.0000 & \multirow{3}{*}{$<0.0001$} \\
\hline & $\begin{array}{l}\text { TAH } \\
\text { BLS }\end{array}$ & 16 & 107.0000 & 20.2748 & 76.0000 & 143.0000 & 107.5000 & \\
\hline & $\begin{array}{l}\text { TAH } \\
\text { BSO } \\
\end{array}$ & 19 & 148.8947 & 22.5509 & 117.0000 & 190.0000 & 144.0000 & \\
\hline
\end{tabular}

\begin{tabular}{|c|c|c|c|c|c|c|c|c|}
\hline & & No. & Mean & SD & Mini. & Maxi. & Median & $\begin{array}{c}\text { p- } \\
\text { Value }\end{array}$ \\
\hline \multirow{3}{*}{$\begin{array}{l}\text { LDL } \\
6 \mathrm{~m}\end{array}$} & TAH & 10 & 110.4000 & 12.3935 & 87.0000 & 129.0000 & 111.0000 & \multirow{3}{*}{$<0.0001$} \\
\hline & $\begin{array}{l}\text { TAH } \\
\text { BLS }\end{array}$ & 16 & 116.4375 & 21.2539 & 86.0000 & 152.0000 & 111.5000 & \\
\hline & $\begin{array}{l}\text { TAH } \\
\text { BSO }\end{array}$ & 19 & 160.9474 & 22.2398 & 137.0000 & 199.0000 & 153.0000 & \\
\hline \multicolumn{9}{|c|}{ Table 11. Distribution of Mean LDL 6M in Groups } \\
\hline
\end{tabular}

\begin{tabular}{|c|c|c|c|c|c|c|c|c|}
\hline & & No. & Mean & SD & Mini. & Maxi. & Median & $\begin{array}{c}\text { p- } \\
\text { Value }\end{array}$ \\
\hline $\begin{array}{c}\text { TC } \\
\text { Pre- } \\
\text { Op }\end{array}$ & TAH & 10 & 145.4000 & 20.4081 & 123.0000 & 164.0000 & 153.0000 & \\
\cline { 2 - 7 } TAH BLS & 16 & 160.3125 & 16.9380 & 134.0000 & 187.0000 & 165.0000 & $<0.0001$ \\
\hline \multicolumn{10}{|c|}{ Table 12. Distribution of Mean TC Pre-Op in Groups } & \\
\hline \multicolumn{10}{c|}{} & TAH & 190.4211 & 25.1359 & 138.0000 & 241.0000 & 194.0000 & \\
\hline
\end{tabular}

\begin{tabular}{|c|c|c|c|c|c|c|c|c|}
\hline & & No. & Mean & SD & Mini. & Maxi. & Median & $\begin{array}{c}\text { p- } \\
\text { Value }\end{array}$ \\
\hline \multirow{2}{*}{$\begin{array}{c}\text { TC } \\
\text { 3 m }\end{array}$} & TAH & 10 & 150.0000 & 19.8886 & 128.0000 & 168.0000 & 158.0000 & \\
\cline { 2 - 6 } & TAH BLS & 16 & 171.6250 & 19.1551 & 145.0000 & 210.0000 & 173.5000 & $<0.0001$ \\
\cline { 2 - 6 } & TAH BSO & 19 & 217.0526 & 22.7241 & 182.0000 & 260.0000 & 210.0000 & \\
\hline \multicolumn{6}{|c|}{ Table 13. Distribution of Mean TC 3 Mon. in Groups } \\
\hline
\end{tabular}

\begin{tabular}{|c|c|c|c|c|c|c|c|c|}
\hline & & No. & Mean & SD & Mini. & Maxi. & Median & $\begin{array}{c}\text { p- } \\
\text { Value }\end{array}$ \\
\hline \multirow{2}{*}{$\begin{array}{c}\text { TC } \\
\mathbf{6}\end{array}$} & TAH & 10 & 170.5000 & 12.2406 & 152.0000 & 189.0000 & 168.0000 & \\
\cline { 2 - 8 } & TAH BLS & 16 & 178.5333 & 19.6936 & 152.0000 & 216.0000 & 178.0000 & $<0.0001$ \\
\cline { 2 - 7 } & TAH BSO & 19 & 232.2105 & 21.1123 & 200.0000 & 270.0000 & 226.0000 & \\
\hline \multicolumn{7}{|c|}{ Table 14. Distribution of Mean TC 6 m in Groups } \\
\hline
\end{tabular}

\section{Statistical Analysis}

For statistical analysis data were entered into a Microsoft excel spreadsheet and then analysed by SPSS (Version 24.0; SPSS Inc., Chicago, IL, USA). Data had been summarized as mean and standard deviation for numerical variables.

\section{RESULTS}

We found that in TAH, the mean age (mean \pm S.D.) of patients was $42.7000 \pm .9487$ years. In TAH BLS, the mean age (mean \pm S.D.) of patients was $42.5625 \pm 2.9205$ years. In TAH BSO, the mean age (mean \pm S.D.) of patients was $47.4211 \pm 3.6563$ years. Difference of mean age vs. group was statistically significant $(\mathrm{p}<0.0001)$.

It was found that in TAH, $6(60.0 \%)$ patients had Dub and $4(40.0 \%)$ patients had fibroid. In TAH BLS, 3 (18.8\%) patients had adenomyosis, $12(75.0 \%)$ patients had fibroid and $1(6.3 \%)$ patient had menorrhagia. In TAH BSO, 1 (5.3\%) patients had adenomyosis, 5 (26.3\%) patients had Dub, 3 (15.8\%) patients had fibroid and $10(52.6 \%)$ patients had menorrhagia. Association of indication in three groups was statistically significant $(\mathrm{p}<0.0001)$.

Among TAH, the mean pre op TG (mean \pm S.D.) of patients was $101.4000 \pm 21.4900$. In TAH BLS, the mean pre op TG (mean \pm S.D.) of patients was $119.1250 \pm 25.1843$. In TAH BSO, the mean pre op TG (mean \pm S.D.) of patients was 
$165.7368 \pm 12.7360$. Difference of mean pre op TG vs. group was statistically significant $(\mathrm{p}<0.0001)$.

It was seen that in $\mathrm{TAH}$, the mean total glyceride at 3 months (mean \pm S.D.) of patients was $113.8000 \pm 17.0542$. In TAH BLS, the mean total glyceride at 3 months (mean \pm S.D.) of patients was $127.8750 \pm 25.0197$. In TAH BSO, the mean total glyceride at 3 months (mean \pm S.D.) of patients was $190.4737 \pm 15.2584$. Difference of mean total glyceride at 3 months vs. group was statistically significant $(\mathrm{p}<0.0001)$.

We noticed that in TAH, the mean TG at 6 months (mean \pm S.D.) of patients was $137.3750 \pm 14.2120$. In TAH BLS, the mean TG at 6 months (mean \pm S.D.) of patients was 152.3125 \pm 27.6350 . In TAH BSO, the mean TG at 6 months (mean \pm S.D.) of patients was $202.1579 \pm 13.4340$. Difference of mean TG at 6 months vs. group was statistically significant $(\mathrm{p}<0.0001)$.

In TAH, the mean HDL pre op (mean \pm S.D.) of patients was $53.1000 \pm 8.1302$. In TAH BLS, the mean HDL pre op (mean \pm S.D.) of patients was $46.3125 \pm 6.1179$. In TAH BSO, the mean HDL pre op (mean \pm S.D.) of patients was $41.8421 \pm$ 7.5811. Difference of mean HDL pre op in three groups was statistically significant $(\mathrm{p}=0.0011)$.

We gathered that in TAH, the mean HDL at 3 months (mean \pm S.D.) of patients was $44.2000 \pm 11.0131$. In TAH BLS, the mean HDL at 3 months (mean \pm S.D.) of patients was $41.3125 \pm 6.2580$. In TAH BSO, the mean HDL at 3 months (mean \pm S.D.) of patients was $34.6842 \pm 7.2958$. Difference of mean HDL at 3 months in three groups was statistically significant $(\mathrm{p}=0.0067)$.

In TAH, the mean HDL at 6 months (mean \pm S.D.) of patients was $47.1000 \pm 14.2552$. In TAH BLS, the mean HDL at 6 months (mean \pm S.D.) of patients was $38.6250 \pm 6.2597$. In TAH BSO, the mean HDL at 6 months (mean \pm S.D.) of patients was $33.4211 \pm 8.2146$. Difference of mean HDL at 6 months in three groups was statistically significant $(\mathrm{p}=0.0022)$.

It was found that in TAH, the mean Pre op LDL (mean \pm S.D.) of patients was $78.0000 \pm 26.7291$. In TAH BLS, the mean Pre op LDL (mean \pm S.D.) of patients was $93.8750 \pm$ 18.0217. In TAH BSO, the mean Pre op LDL (mean \pm S.D.) of patients was $121.5789 \pm 23.0562$. Difference of mean Pre op LDL in three groups was statistically significant $(\mathrm{p}<0.0001)$.

We have seen that in TAH, the mean LDL at 3 months (mean \pm S.D.) of patients was $82.8000 \pm 26.4146$. In TAH BLS, the mean LDL at 3 months (mean \pm S.D.) of patients was $107.0000 \pm 20.2748$. In TAH BSO, the mean LDL at 3 months (mean \pm S.D.) of patients was $148.8947 \pm 22.5509$. Difference of mean LDL at 3 months in three groups was statistically significant $(\mathrm{p}<0.0001)$.

In TAH, the mean LDL at 6 months (mean \pm S.D.) of patients was $110.4000 \pm 12.3935$. In TAH BLS, the mean LDL at 6 months (mean \pm S.D.) of patients was $116.4375 \pm$ 21.2539. In TAH BSO, the mean LDL at 6 months (mean \pm S.D.) of patients was $160.9474 \pm 22.2398$. Difference of mean LDL at 6 months in three groups was statistically significant $(\mathrm{p}<0.0001)$.

It was found that in $\mathrm{TAH}$, the mean TC pre op (mean \pm S.D.) of patients was $145.4000 \pm 20.4081$. In TAH BLS, the mean TC pre op (mean \pm S.D.) of patients was $160.3125 \pm$ 16.9380. In TAH BSO, the mean TC pre op (mean \pm S.D.) of patients was $190.4211 \pm 25.1359$. Difference of mean TC pre op in three groups was statistically significant $(p<0.0001)$.
We have seen that in TAH, the mean TC at 3 months (mean \pm S.D.) of patients was $150.0000 \pm 19.8886$. In TAH BLS, the mean TC at 3 months (mean \pm S.D.) of patients was $171.6250 \pm 19.1551$. In TAH BSO, the mean TC at 3 months (mean \pm S.D.) of patients was 217.0526 \pm 22.7241 . Difference of mean TC at 3 months in three groups was statistically significant $(\mathrm{p}<0.0001)$.

In TAH, the mean TC at 6 months (mean \pm S.D.) of patients was $170.5000 \pm 12.2406$. In TAH BLS, the mean TC at 6 months (mean \pm S.D.) of patients was $178.5333 \pm 19.6936$. In TAH BSO, the mean TC at 6 months (mean \pm S.D.) of patients was $232.2105 \pm 21.1123$. Difference of mean TC at 6 months in three groups was statistically significant $(p<0.0001)$.

\section{DISCUSSION}

Our study shows patient with mean age of $42.70 \pm 0.95$ yrs. $(\mathrm{TAH}), 42.56 \pm 2.92(\mathrm{TAH}+\mathrm{BLS}), 47.42 \pm 3.65(\mathrm{TAH}+\mathrm{BSO})$, this difference of age is statistically significant.

In this study the preoperative and postoperative total cholesterol, triglycerides, LDL, levels showed significant increment from preoperative to 3 months and 6 months postoperatively.

HDL value decreased successively in each patient undergoing TAH, TAH + BLS, TAH + BSO postoperatively compared to preoperative values.

To the best of our knowledge this is the only study comparing lipid profile changes in bilateral salpingectomy (Ovaries preserved) to hysterectomy with and without oophorectomy. Total cholesterol changes in bilateral salpingectomy group (TAH + BLS) increased from preoperative value $160.31 \pm 16.94$ to $176.63 \pm 19.16$ (At three months postoperative period), $178.53 \pm 19.69$ (Six months postoperative ) significantly ( $\mathrm{p}<0.001)$. Similarly changes in LDL value was significant from $93.87 \pm 18.02$ (Preoperative) to $107.00 \pm 20.27$ ( 3 months postoperative) \& $116.43 \pm 21.25$ ( 6 months postoperative).

Several cohort studies have reported the relationship between hysterectomy and risk of developing hyperlipidaemia. ${ }^{16-18}$ An Iran study found increased levels of triglyceride, total cholesterol and low-density cholesterol in 31 women six months after their hysterectomy and bilateral salpingo-oophorectomy ${ }^{19}$.

Based on the result analysis, its suggestive that the lipid profile changes in each group of TAH, TAH+BLS, TAH+BSO is significant. TAH + BLS, a ovarian preserving procedure significantly affects the preoperative and postoperative lipid changes ( $p<0.001)$. This allows us to rethink whether sacrificing the fallopian tubes while decreasing the chances of serous ovarian tumours may increase the morbidity due to deranged lipid profile. Most of the patients undergoing BLS where in their reproductive life and subsequent increase in lipid profile will only increase their cardiovascular morbidity.

To be more sure, the study needs to be carried out for a longer duration in order to differentiate whether the changes are in response to stress induced due to surgery or a dysfunctional ovaries.

\section{CONCLUSIONS}

There is significant alteration in lipid profile in all the three groups which leads us to rethink the benefit of ovarian preserving procedure and should motivate the patients for regular follow-up and proper life-style modification and 
appropriate counseling both preoperatively and postoperatively. This allows us to rethink about other conservative approaches in favour of uterus conserving management. We suggest long term follow up pertaining to cardiovascular health including lipid profile. Still, there is a paucity of studies which include the outcome following bilateral salpingectomy; hence more studies are needed in this regard.

\section{REFERENCES}

[1] Szafran H, Smiekal-Korombel W. The role of oestrogens in hormonal regulation of lipid metabolism in women. Przegl Lek 1998;55(5):266-70.

[2] Yakasai IA. Complications of hysterectomy: a review. British Journal of Science 2013;9(2):78-87.

[3] Singh AJ, Arora AK. Effect of uterine prolapse on the lines of rural North Indian women. Singapore J Obstet Gynecol 2003;34:52-8.

[4] Pandey D, Sehgal K, Saxena A, et al. An audit of indications, complications, and justification of hysterectomies at a teaching hospital in India. Article ID 279273, International Journal of Reproductive Medicine 2014;2014:1-6.

ID 2792273: 1-6. 2014; Article ID 2792273: 1-6.

[5] Vitonis AF, Titus-Ernstoff L, Cramer DW. Assessing ovarian cancer risk when considering elective oophorectomy at the time of hysterectomy. Obstet Gynecol 2011;117(5):1042-50.

[6] Rivera CM, Grossardt BR, Rhodes DJ, et al. Increased cardiovascular mortality after early bilateral oophorectomy. Menopause 2009;16(1):15-23.

[7] National Cancer Institute DoCCaPS, Surveillance Research Program, Cancer Statistics Branch. Surveillance, Epidemiology, and End Results (SEER) Program. SEER 12 Incidence and Mortality, DevCan Database. Bethesda, MD, USA: National Cancer Institute, 2004.

[8] Parker WH, Shoupe D, Broder MS, et al. Elective oophorectomy in the gynecological patient: when is it desirable? Curr Opin Obstet Gynecol 2007;19(4):3504.

[9] Parker WH, Broder MS, Chang E, et al. Ovarian conservation at the time of hysterectomy and longterm health outcomes in the nurses' health study. Obstet Gynecol 2009a;113(5):1027-37.
[10] Jacoby VL, Grady D, Wactawski-Wende J, et al. Oophorectomy vs ovarian conservation with hysterectomy: cardiovascular disease, hip fracture, and cancer in the Women's Health Initiative Observational Study. Arch Intern Med 2011;171(8):760-8.

[11] Morse AN, Hammer RA, Walter AJ, et al. Does hysterectomy without adnexectomy in patients with prior tubal interruption increase the risk of subsequent hydrosalpinx? Am J Obstet Gynecol 2002;187(6):1483-6.

[12] Repasy I, Lendvai V, Koppan A, et al. Effect of the removal of the Fallopian tube during hysterectomy on ovarian survival: the orphan ovary syndrome. Eur J Obstet Gynecol Reprod Biol 2009;144(1):64-7.

[13] Morse AN, Schroeder CB, Magrina JF, et al. The risk of hydrosalpinx formation and adnexectomy following tubal ligation and subsequent hysterectomy: a historical cohort study. Am J Obstet Gynecol 2006;194(5):1273-6.

[14] Timor-Tritsch IE, Monteagudo A, Tsymbal T. Threedimensional ultrasound inversion rendering technique facilitates the diagnosis of hydrosalpinx. J Clin Ultrasound 2010;38(7):372-6.

[15] Rezvani M, Shaaban AM. Fallopian tube disease in the nonpregnant patient. Radiographics 2011;31(2):52748.

[16] Howard B. Risk of cardiovascular disease by hysterectomy status, with and without oophorectomy: the Women's Health Initiative Observational Study. Circulation 2005;111(12):1462-70.

[17] Kabir F, Jahan N, Sultana N, et al. Lipid profile status in surgical menopause. Journal of Bangladesh Society of Physiologist 2011;6(2):127-33.

[18] Tuna V, Alkis I, Safiye AS, et al. Variations in blood lipid profile, thrombotic system, arterial elasticity and psychosexual parameters in the cases of surgical and natural menopause. Aust N Z J Obstet Gynaecol 2010;50(2):194-9.

[19] Yazdani S, Sharbatdaran M, Samakoosh AM, et al. Glucose tolerance and lipid profile changes after surgical menopause. Caspian J Intern Med 2014;5(2):114-7. 